\title{
BEBERAPA FAKTOR YANG MEMPENGARUHI KONTRIBUSI PENGAMBILAN KEPUTUSAN DI RUMAH TANGGA (KASUS PNS PEREMPUAN YANG MENIKAH DI KABUPATEN TABANAN)
}

\author{
Ni Putu Sri Eka Lestari ${ }^{1}$ \\ Wayan Sudirman ${ }^{2}$ \\ ${ }^{1,2}$ Fakultas Ekonomi dan Bisnis Universitas Udayana (Unud), Bali, Indonesia \\ Email : lestarieka234@gmail.com
}

\begin{abstract}
ABSTRAK
Penelitian ini bertujuan untuk menganalisis, 1) kontribusi pengambilan keputusan dalam rumah tangga perempuan PNS yang telah menikah di Kabupaten Tabanan, 2) pengaruh pendidikan istri, pendidikan suami, umur, alokasi waktu, dan jabatan terhadap pendapatan istri PNS perempuan yang telah menikah di Kabupaten Tabanan, 3) pengaruh pendidikan istri, pendidikan suami, umur, alokasi waktu, jabatan dan pendapatan istri terhadap kontribusi pengambilan keputusan PNS perempuan yang telah menikah di Kabupaten Tabanan, dan 4) pendapatan istri dalam memediasi pengaruh pendidikan istri, pendidikan suami, umur, alokasi waktu dan jabatan terhadap kontribusi pengambilan keputusan PNS perempuan yang telah menikah di Kabupaten Tabanan. Hasil penelitian menunjukkan pendidikan istri, umur, alokasi waktu, dan jabatan berpengaruh positif dan signifikan terhadap pendapatan istri PNS perempuan yang telah menikah di Kabupaten Tabanan. Adapun variabel pendidikan suami berpengaruh negatif dan tidak signifikan terhadap pendapatan istri PNS perempuan yang telah menikah di Kabupaten Tabanan. Pendapatan istri memediasi pengaruh pendidikan istri, umur, alokasi waktu dan jabatan terhadap kontribusi pengambilan keputusan PNS perempuan yang telah menikah di Kabupaten Tabanan. Adapun variabel pendapatan istri tidakmemediasi pengaruh pendidikan suami terhadap kontribusi pengambilan keputusan PNS perempuan yang telah menikah di Kabupaten Tabanan.
\end{abstract}

Kata kunci: pendapatan istri, kontribusi pengambilan keputusan, rumah tangga

\section{ABSTRACT}

This study aims to analyze, 1) the contribution of decision making in the household of married civil servants in Tabanan District, 2) the influence of wife education, husband education, age, time allocation, and position to the income of married female civil servant wife in Tabanan District, 3) the influence of wife's education, husband's education, age, time allocation, position and income of wife to contribution of decision of married woman civil servant in Tabanan regency; and 4) wife income in mediating wife's education influence, husband's education, age, and positions on the contribution of civil servant marriage decision making in Tabanan regency. The result of the research shows that wife education, age, time allocation, and position have positive and significant effect to income of married female civil servant wife in Tabanan regency. The husband education variable has a negative and insignificant effect on the income of female civil servant wife who has been married in Tabanan regency. Wives income mediates the influence of wife's education, age, time allocation and position on contribution of decision making of married woman civil servant in Tabanan regency. The income variable of the wife does not mediate the influence of husband education on the contribution of decision making of married women civil servants in Tabanan regency.

Keywords: wife income, decision contribution, household 


\section{PENDAHULUAN}

Pengambilan keputusan menyangkut masalah rumah tangga sering melibatkan laki-laki dan perempuan yang telah menikah. Pendidikan, pemanfaatan pendapatan, kepemilikan kekayaan keluarga, kegiatan luar rumah tangga, penyaluran aspirasi dan pengelolaan rumah tangga (pekerjaan dapur, kebersihan rumah dan mengasuh anak), dan lainnya merupakan contoh bidang pengambilan keputusan. Menurut Sunaryo dan Zuriah (2004) persoalan penting dan dalam skala yang besar bagi keluarga keputusan yang diambil sebaiknya dilakukan musyawarah suami dan istri secara setara.

Gender dikonstruksikan masyarakat adalah perilaku-perilaku dan harapanharapan yang dikaitkan kepada perempuan dan laki-laki (Laporan Penelitian Bank Dunia, 2002). Nilai, norma yang dianut, agama, kepercayaan dan yang lain-lain yang tergantung pada perwujudan suatu gender dalam masyarakat tidak selalu sama. Mencari nafkah dan memenuhi kebutuhan sandang, pangan dan papan merupakan tugas dari seorang suami secara umum sebagai kepala keluarga. Selain suami, istri juga mempunyai peran yang sangat penting, yaitu sebagai pendamping suami di setiap saat dan ibu yang siap menjaga dan membimbing anak-anaknya.

Secara umum seorang suami berperan sebagai kepala keluarga yang bertugas mencari nafkah untuk memenuhi kebutuhan sandang, pangan dan papan. Membimbing istri dan mengayomi istri agar tetap di jalan yang benar juga merupakan peran dari seorang suami. Membantu dan meringanka tugas istri merupakan hal yang sangat penting untuk dilakukan suami, selain menjadi rekan seorang istri. 
Membimbing anak-anak, menjaga dan menjadi pendamping suami merukan hal penting yang dilakukan seorang istri (Dewi, 2011 dalam Lestari, 2015).

Kenyataan, terdapat perbedaan peran antara suami dan istri di kehidupan berumah tangga. Menurut Sunaryo dan Zuriah (2004) penentuan urusan keluarga lebih banyak ditentukan oleh istri, sedangkan hal-hal yang berkaitan dengan pemanfaatan pendapatan, pemilikan kekayaan keluarga, penentuan kegiatan luar rumah dan penyaluran aspirasi lebih banyak ditentukan oleh seorang suami. Istri lebih berperan dalam pengambilan keputusan yang bersifat domestik dan reproduktif.

Suami tetap mendominasi pengambilan keputusan secara publik karena suami memiliki tugas sebagai pemimpin keluarga yang bertanggung jawab pada nafkah keluarga. Sehingga semua hal yang berkaitan dengan penggunaan pendapatan tetap diputuskan oleh suami (Wiludjeng dkk, 2005). Istri lebih berperan dalam pengambilan keputusan yang bersifat domestik dan reproduktif. Pembagian peran yang demikian dirasa kurang seimbang karena dirasa istri masih kurang berpartisipasi dalam keikutsertaan pengambilan keputusan dalam rumah tangga. Hal ini boleh jadi dikarenakan pandangan masyarakat awam terhadap perempuan yang selalu menempatkan bahwa kaum perempuan belum sejajar dengan kaum laki-laki.

Pembagian tugas dalam menjalankan fungsi keluarga menuju terwujudnya tujuan keluarga sangat membutuhkan gender untuk menjaga keseimbangan dalam keluarga. Saling menjaga, membagi peran dan tugas sehari-hari, bertanggung jawab pada peran dan tugas masing-masing merupakan komitmen bersama suami dan istri. (Puspitawati, 2010). Walgito (2000) mengemukakan bahwa suami dan istri dalam 
kehidupah berumah tangga memiliki hak dan kedudukan yang sama dalam mengatur keluarganya.

Kebebasan bersuara, berpendapat dan mengaktualisasi dirinya sehingga terbentuk sebuah sinergritas yang saling menuntungkan satu sama lain merupakan hak dan kesempatan perempuan dan laki-laki Mudzhar dkk, 2001). Oleh karenanya, sangat diperlukan sikap saling menghargai antar suami istri dalam mengambil keputusan agar terciptanya keharmonisan dalam keluarga dan terbentuk keluarga yang sejahtera. Sekarang perempuan tidak hanya berkecimpung di dunia domestik saja, tetapi juga telah dunia publik. Banyak faktor yang menyebabkan perempuan untuk terjun ke ranah publik salah satunya adalah karena kebutuhan hidup yang harus dipenuhi karena semakin lama kebutuhannya semakin meningkat.

Pertumbuhan pribadi seorang anak sangat berpengaruh pada keteladanan seorang ibu, sebagai makhluk sosial yang mempunyai tanggung jawab membina keluarga sepenuhnya, karena pada diri perempuan terdapat suatu tugas yang memiliki fungsi yang sangat dominan dalam keluarga. Masuknya perempuan dalam ranah publik bukan lagi menjadi suatu hal yang tabu. Berdalih dengan alasan kebutuhan ekonomi yang semakin meningkat, membuat masuknya mereka dalam ranah publik menjadi semakin mulus (Ariesta, 2014).

Perempuan mempunyai fungsi yang sangat mendominan pada keluarga, karena pada diri perempuan terdapat suatu tanggung jawab sebagai makhluk sosial yang mempunyai tugas dan kewajiban membina keluarga sepenuhnya, seperti pertumbuhan pribadi anak dimana keteladanan seorang ibu sangat berpengaruh 
terhadap anak. Mengerjakan rumah tangga sudah bukan kodrat seorang perempuan sebagai ibu rumah tangga lagi, tetapi sudah berkembang sehingga istri juga telah berkembang dalam kehidupan bermasyarakat yang merupakan peran perempuan di masa sekarang, dimana sudah terdapat emansipasi.

Pendidikan istri sangat penting dimana pada masa sekarang ini emansipasi dan kesetaraan gender menjadi hal penting yang sedang diperjuangkan oleh kaum perempuan, maka pendidikan sudah tidak lagi menjadi monopoli bagi kaum laki-laki, tetapi sudah menjadi kewajiban kaum perempuan untuk mengenyamnya sampai pada tingkatan yang paling tinggi. Tidak sedikit perempuan memiliki pendidikan yang setara atau bahkan ada yang memiliki pendidikan lebih tinggi dari suaminya. Tingginya pendidikan seorang perempuan tentu akan mempengaruhi besarnya kontribusi seorang perempuan dalam pengambilan keputusan pada keluarganya masing-masing. Kecendrungannya dengan semakin tinggi tingkat pendidikan perempuan, maka kemungkinan keputusan yang diambil dalam suatu rumah tangga, lebih bisa dijadikan acuan dalam suatu keluarga.

Tidak hanya pendididikan istri, ternyata pendidikan suami juga menjadi salah satu faktor yang mendasari kesetaraan pengambilan keputusan pada rumah tangga. Pendidikan suami yang tinggi akan cenderung menjadikan suami memonopoli setiap keputusan penting di rumah tangga. Sebaliknya pendidikan suami yang lebih rendah suaminya cenderung menjadikan perempuan atau sang istri lebih dominan dalam membuat keputusan dalam rumah tangga baik di sektor domestik maupun sektor publik. 
Selain pendidikan, baik pendidikan suami dan pendidikan istri, umur perempuan juga mempengaruhi seseorang dalam pengambilan keputusan yang demokratis pada sebuah keluarga. Biasanya dengan semakin dewasa umur seseorang, maka tingkat emosional dan cara berfikir juga menjadi lebih baik, sehingga kemampuan untuk melakukan analisa dan pemecahan problematik dalam sebuah keluarga menjadi lebih baik. Sebaliknya semakin muda umur seorang maka tingkat emosionalnya masih belum terkontrol untuk keikutsertaan dalam mengambil keputusan untuk menjamin keluarga yang seimbang.

Alokasi waktu juga menjadi salah satu faktor yang mempengaruhi kontribusi dari perempuan dalam mengambil keputusan dalam rumah tangganya. Alokasi waktu yang banyak di luar sangat mempengaruhi peran perempuan dalam rumah tangganya. Selain sebagai karyawan ibu rumah tangga juga bertugas mengatur rumah tangga, selain itu tidak sedikit juga wanita yang aktif di kegiatan luar sehingga waktu yang dimiliki cenderung sedikit dan mengurangi kontribusi dalam mengambil keputusan rumah tangga. Mengingat kebanyakan ibu rumah tangga ada yang aktif di banjar, pkk ataupun lainnya yang berhubungan dengan sosial.

Jabatan istri yang semakin meningkat, sampai pada jenjang jabatan tertinggi di tempatnya bekerja. Jabatan ini tentu akan berpengaruh terhadap kontribusi seorang istri dalam pengambilan keputusan baik di tempat kerja maupun di rumah tangga. Jabatan sesorang juga dapat mempengaruhi pendapatan sesorang, sehingga mempengaruhi kontribusi dalam kedudukan istri terhadap suami dalam suatu keluarga. Di era sekarang ini banyak perempuan yang mengejar dan memiliki karier 
yang tinggi, bahkan ada yang memiliki pekerjaan dan jabatan lebih baik dari suaminya. Kondisi ini cenderung menjadikan kaum istri bisa menjadi lebih dominan dibandingkan suami dalam pengambilan keputusan karena menganggap diri lebih baik dari suaminya. Hal ini sebenarnya terbalik dengan keinginan suami yang mengharapkan istri dengan tingkat pendidikan yang tinggi, dan karir yang baik bisa membantu suami dalam meningkatkan pendapatan keluarga, sehingga bisa lebih memberi kontribusi kepada keluarga dalam setiap mengambil keputusan bersama seorang suami. Keputusan yang diambil haruslah sama dan sejalan antara seorang istri dan suami, dalam arti keputusan keluarga yang harus saling melengkapi dan saling mendukung.

Setelah bekerja dengan profesi, umur, alokasi waktu bahkan jabatan yang baik seorang istri tentu akan mendapatkan pendapatan dari hasil pekerjaannya, terkadang pendapatan juga menjadi salah satu tolak ukur untuk kontribusi perempuan dalam mengambil keputusan dalam rumah tangga. Jika pendapatan tinggi kemungkinan peran dalam mengambil keputusan juga tinggi, begitu juga sebaliknya. Perempuan yang bekerja dan memiliki penghasilan sendiri cenderung lebih dihargai dan pendapatnya didengarkan oleh sang suami.

\section{METODE PENELITIAN}

Kuantitatif merupakan metode yang digunakan dalam penelitian ini, dengan data primer yang diperoleh melalui penyebaran kuisioner yang diisi oleh responden. Populasi terdiri dari 3.919 orang PNS perempuan yang telah menikah di Kabupaten 
Tabanan. Stratified random sampling merupakan teknik penentuan sampel yang digunakan pada penelitian ini. Dengan tingkat eror $10 \%$ dan dihitung memakai rumus slovin maka sampel yang akan diteliti berjumlah 98 digunakan 100 sampel PNS perempuan yang telah menikah di Kabupaten Tabanan.

Penelitian ini memiliki variabel terikat yaitu, adalah kontribusi pengambilan keputusan PNS perempuan yang telah menikah di Kabupaten Tabanan. Penelitian ini juga memiliki variabel bebas, yaitu pendidikan istri, pendidikan suami, umur, alokasi waktu dan jabatan. Dalam penelitian ini juga terdapat variabel antara (intervening) yang dalam penelitian ini variabel pendapatan istri. Definisi operasional variabel yang digunakan sebagai berikut:

a. Pendidikan istri (X1) adalah jenjang pembelajaran formal dari responden, yang dalam dalam hal ini adalah PNS perempuan yang telah menikah di Kabupaten Tabanan dalam satuan tahun.

b. Pendidikan suami (X2) adalah jenjang pembelajaran formal suami dari responden dalam satuan tahun.

c. Umur (X3) adalah lama hidup seseorang sejak lahir sampai dengan penelitian ini dilakukan yang diukur dalam satuan tahun. Dalam variabel ini umur dimasukkan untuk usia PNS informal dihitung dari ulang tahun terakhir.

d. Alokasi waktu (X4) adalah pengaturan dan tata cara penyusunan rencana dalam sehari bagi PNS perempuan yang diukur dalam satuan jam /hari. 
e. Jabatan (X5) adalah nilai sebuah kepercayaan yang diberikan dimana berisikan tugas, tanggung jawab dan fungsi yang spesifik yang diukur dalam skala nominal.

f. Pendapatan istri (Y1) adalah jumlah uang yang diterima oleh responden dari aktifitasnya selama satu bulan yang diukur dalam rupiah/bulan.

g. Kontribusi pengambilan keputusan (Y2) adalah partisipasi responden dalam menilai dan menentukan pilihan terkait urusan di rumah tangga, satuannya menggunakan skala nominal.

Model dapat dilihat pada gambar 1.

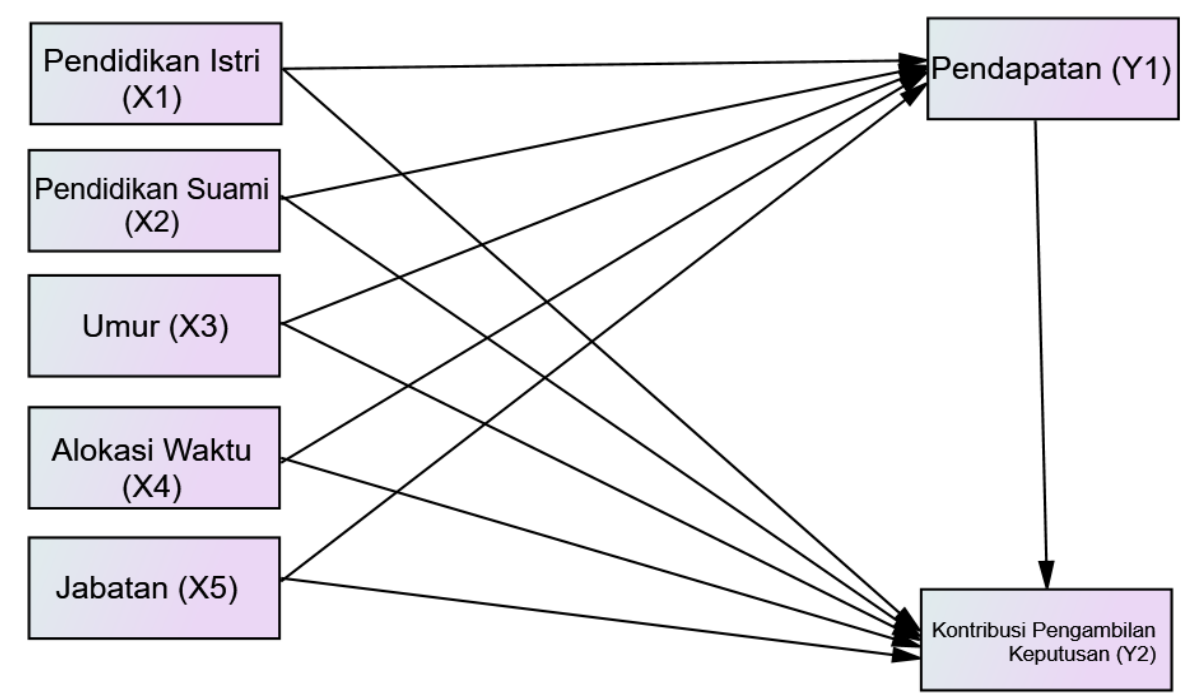

Gambar 1

Kerangka Konsep Penelitian 


\section{TEKNIK ANALISIS DATA}

1. Analisis Deskritif

Suatu penelitian yang sebenarnya menggunakan statistik deskriptif untuk membantu menggambarkan keadaaan (fakta). Analisis ini bermanfaat memberi informasi yang berguna akan diberikan oleh metode-metode pengumpuluan dan penyajian data.

\section{Analisis Jalur (path analysis)}

Untuk menaksir hubungan kausalitas antara antar variabel merupakan analisis jalur merupakan perluasan dari analisis regresi linear berganda. Hubungan sebab akibat antara satu variabel dengan variabel lainnya dapat menggunaka analisis jalur untuk menganalisisnya. Hubungan sebab akibat yang dihipotesiskan dapat mengestimasi koefisien-koefisien sejumlah persamaan linear yang mewakili prosedur ini. Analisis jalur memiliki suatu variabel yang memiliki peran ganda, satu sisi suatu variabel bisa sebagai variabel bebas dalam suatu hubungan namun menjadi variabel terikat pada hubungan lain mengingat adanya hubungan kausal yang betingkat. Pengaruh langsung dan pengaruh tidak langsung dari suatu variabel merupakan fungsi dari analisis jalur, dimana beberapa variabel dianggap sebagai penyebab dari variabel lainnya (Suyana Utama, 2010).

Persamaan struktural analisis jalur:

$$
\begin{aligned}
& Y_{1}=\beta_{1} X_{1}+\beta_{2} X_{2}+\beta_{3} X_{3}+\beta_{4} X_{4}+\beta_{5} X_{5} \epsilon_{1} \\
& Y_{2}=\beta_{6} X_{1}+\beta_{7} X_{2}+\beta_{8} X_{3}+\beta_{9} X_{4}+\beta_{10} X_{5}+\beta_{11} Y_{1}+\epsilon_{2}
\end{aligned}
$$




\section{HASIL PENELITIAN}

Hubungan antar variabel dalam model analisis jalur model ini adalah bersifat linier dan aditif. Apabila model signifikan atau non signifikan berarti dapat dikatakan model berbentuk linier dalam uji linieritas menggunakan curve fit dan menerapkan prinsip parsimony.

\section{Tabel 1}

Hubungan Linier Antar Variabel Penelitian

\begin{tabular}{cccc}
\hline Hubungan Variabel & R-Square & F & Sig. \\
\hline X1 -> Y1 & 0,120 & 13,387 & 0,000 \\
X2 -> Y1 & 0,003 & 0,312 & 0,578 \\
X3 -> Y1 & 0,109 & 12,020 & 0,001 \\
X4 -> Y1 & 0,157 & 18,216 & 0,000 \\
X5 -> Y1 & 0,274 & 37,011 & 0,000 \\
X1 -> Y2 & 0,089 & 9,594 & 0,003 \\
X2 -> Y2 & 0,046 & 4,766 & 0,031 \\
X3 -> Y2 & 0,091 & 9,853 & 0,002 \\
X4 -> Y2 & 0,005 & 0,540 & 0,464 \\
X5 -> Y2 & 0,124 & 13,850 & 0,000 \\
Y1 -> Y2 & 0,201 & 24,584 & 0,000
\end{tabular}

Sumber: Data Penelitian, 2017

Berdasarkan tabel 1 dapat dilihat bahwa terdapat dua variabel yang tidak berhubungan secara linear satu dengan yang lainnya, yaitu hubungn antar variabel X2 -> Y1 dan X4 ->Y2. Hasil ini ditunjukkan oleh signifikansi yang lebih besar dari 0,05. Hubungan antara variabel lainnya menunjukkan hubungan yang linear dilihat dari nilai signifikan kurang dari 0,05. Hubungan yang paling linear adalah antara X5 > Y1, yaitu ditunjukkan oleh F-Hitung terbesar, yaitu sebesar 37,011.

\section{Evaluasi terhadap Validitas Model}


$\mathrm{R}^{2}$ dari variabel dependen dapat menggambarkan validitas model struktural. Pada tabel 2 menunjukkan nilai $\mathrm{R}^{2}$ variabel dependen dalam penelitian ini.

\section{Tabel 2}

Hasil Evaluasi Validitas Model

\begin{tabular}{|c|c|c|c|c|}
\hline \multirow[t]{2}{*}{ No } & Variabel & Variabel & $\mathrm{R} 2$ & $\begin{array}{l}\text { Kemampuan } \\
\text { Menjelaskan }\end{array}$ \\
\hline & Dependen & Independen & & Variabel Independen \\
\hline 1 & Pendapatan Istri & $\mathrm{X} 1, \mathrm{X} 2, \mathrm{X} 3, \mathrm{X} 4, \mathrm{X} 5$ & 0,418 & Sedang \\
\hline 2 & Kontribusi & $\mathrm{X} 1, \mathrm{X} 2, \mathrm{X} 3, \mathrm{X} 4, \mathrm{X} 5, \mathrm{Y} 1$ & 0,455 & Sedang \\
\hline
\end{tabular}

Sumber: Data Penelitian, 2017

Dalam penelitian ini terdapat dua variabel dependen, yaitu pendapatan istri (Y1) dan kontribusi pengambilan keputusan (Y2). Terhadap kedua variabel dependen, variabel independen memberikan nilai pendapatan istri (Y1) memberikan nilai 0,4 sehingga variabel independen terhadap variabel dependen tergolong sedang. Sedangkan variabel kontribusi (Y2) memberikan nilai 0,4 sehingga variabel independen terhadap variabel dependen juga tergolong sedang.

Koefisien determinasi total persamaan struktural dari model penelitian ini dengan perhitungan sebagai berikut:

$$
\begin{aligned}
& R_{m}^{2}=1-(0,763)^{2}(0,738)^{2} \\
& R_{m}^{2}=1-(0,582)(0,545) \\
& R_{m}^{2}=1-0,317 \\
& R_{m}^{2}=0,683
\end{aligned}
$$

Koefisien determinan total sebesar 0,683 memiliki pengertian bahwa sebesar 68,3 persen variabel dari kontribusi dapat dijelaskan oleh model yang dibentuk, 
sedangkan sisanya sebesar 31,7 persen dijelaskan oleh variabel lain diluar model yang dibentuk.

\section{Pengaruh Langsung}

Analisis pengaruh langsung dan tidak langsung maupun pengaruh total dapat menjelaskan hubungan antar variabel. Pengaruh tidak langsung ditujukan oleh koefisien semua anak panah dengan satu ujung, sebaliknya pengaruh tidak langsung terjadi melalui peran satu atau beberapa variabel antara. Pada tabel 3 menampilkan hasil olahan data path coefficients untuk mengetahui pengaruh langsung antar variabel konstruk.

Tabel 3

Path Coefficient

\begin{tabular}{ccccc}
\hline $\begin{array}{c}\text { Hubungan } \\
\text { Variabel }\end{array}$ & $\begin{array}{c}\text { Coefficient } \\
\text { Standar }\end{array}$ & $\begin{array}{c}\text { Standar } \\
\text { Error }\end{array}$ & P-Value & Keterangan \\
\hline X1 -> Y1 & 0,101 & 0,029 & 0,001 & Sig. \\
X2 -> Y1 & $-0,047$ & 0,027 & 0,086 & Non Sig. \\
X3 -> Y1 & 0,018 & 0,008 & 0,033 & Sig. \\
X4 -> Y1 & 0,196 & 0,066 & 0,004 & Sig. \\
X5 -> Y1 & 0,464 & 0,142 & 0,001 & Sig. \\
X1 -> Y2 & 0,082 & 0,029 & 0,006 & Sig. \\
X2 -> Y2 & $-0,113$ & 0,025 & 0,000 & Sig. \\
X3 -> Y2 & 0,015 & 0,008 & 0,050 & Sig. \\
X4 -> Y2 & $-0,220$ & 0,065 & 0,001 & Sig. \\
X5 -> Y2 & 0,360 & 0,140 & 0,012 & Sig. \\
Y1 -> Y2 & 0,301 & 0,096 & 0,002 & Sig. \\
\hline
\end{tabular}

Sumber: Data Penelitian, 2017

Berdasarkan tabel 3 dapat dilihat bahwa pendidikan istri berpengaruh positif dan signifikan terhadap pendapatan istri. Hal ini ditunjukkan dengan koefisien path sebesar 0,101 dan tingkat signifikan kurang dari 0,05 yaitu dengan nilai p-value 
0,001. Hal ini berarti semakin tinggi tingkat pendidikan seseorang istri, maka pendapatan yang diterima akan semakin tinggi. Pendidikan istri berpengaruh positif dan signifikan terhadap kontribusi pengambilan keputusan, dengan koefisien path sebesar 0,129 dan tingkat signifikansi lebih kecil dari 0,05 dengan nilai p-value sebesar 0,006. Hal ini berarti semakin tinggi pendidikan istri maka kontribusi dalam mengambil keputusan juga akan semakin tinggi.

Pendidikan suami berpengaruh negatif dan tidak signifikan terhadap pendapatan istri. Hal ini berarti hipotesis ditolak dan ditunjukkan dengan koefisien path sebesar -0,047 dengan tingkat signifikansi lebih besar dari 0,05 yaitu dengan pvalue sebesar 0,086. Hal ini berarti pendidikan suami tidak memiliki pengaruh yang signifikan terhadap pendapatan. Pendidikan suami berpengaruh negatif dan signifikan terhadap kontribusi dalam mengambil keputusan. Hal ini berarti hipotesis ditolak dan ditunjukkan dengan koefisien path sebesar -0,177 dengan tingkat signifikansi lebih kecil dari 0,05 yaitu dengan p-value sebesar 0,000. Hal ini berarti pendidikan suami tinggi maka kontribusi dalam mengambil keputusan rendah dan begitu sebaliknya.

Umur berpengaruh positif dan signifikan terhadap pendapatan istri. Hal ini ditunjukkan dengan koefisien path sebesar 0,018 dan tingkat signifikansi lebih kecil dari 0,05 dengan nilai p-value sebesar 0,033. Hal ini berarti semakin tua umur, maka pendapatan yang diterima akan semakin tinggi karena saat perempuan memasuki usia produktif, semakin lama perempuan bekerja maka pengalaman kerja yang dimiliki juga banyak. Umur berpengaruh positif dan signifikan terhadap kontribusi dalam mengambil keputusan. Hal ini ditunjukkan dengan koefisien path sebesar 0,024 dan 
tingkat signifikansi lebih kecil dari 0,05 dengan nilai p-value sebesar 0,050. Hal ini berarti semakin tua umur, maka kontribusi dalam mengambil keputusan semakin tinggi karena umur mempengaruhi emosi dan pola pikir seseorang.

Alokasi waktu memiliki pengaruh positif dan signifikan terhadap pendapatan istri. Hal ini ditunjukan dengan koefisian path sebesar 0,196 dan tingkat signifikansi lebih kecil dari 0,05 dengan nilai p-value sebesar 0,004. Hal ini berarti semakin lama alokasi waktu untuk bekerja, maka pendapatan yang diterima akan semakin tinggi. Alokasi waktu memiliki pengaruh negatif dan signifikan terhadap kontribusi dalam mengambil keputusan yang berarti menolak hipotesis. Hal ini ditunjukan dengan koefisian path sebesar $-0,346$ dan tingkat signifikansi lebih kecil dari 0,05 dengan nilai p-value sebesar 0,001. Hal ini berarti semakin lama alokasi waktu untuk bekerja, maka kontribusi dalam mengambil keputuan akan semakin kecil.

Jabatan memiliki pengaruh positif dan signifikan terhadap pendapatan istri. Hal ini ditunjukan dengan koefisian path sebesar 0,311 dan tingkat signifikansi lebih kecil dari 0,05 dengan nilai p-value sebesar 0,001. Hal ini berarti semakin tinggi jabatan, maka pendapatan yang diterima juga akan semakin tinggi. Jabatan memiliki pengaruh positif dan signifikan terhadap kontribusi dalam mengambil keputusan. Hal ini ditunjukan dengan koefisian path sebesar 0,567 dan tingkat signifikansi lebih kecil dari 0,05 dengan nilai p-value sebesar 0,012. Hal ini berarti semakin tinggi jabatan, maka kontribusi dalam mengambil keputusan juga akan semakin tinggi.

Pendapatan istri memiliki pengaruh positif dan signifikan terhadap kontribusi dalam mengambil keputusan. Hal ini ditunjukan dengan koefisian path sebesar 0,473 
dan tingkat signifikansi lebih kecil dari 0,05 dengan nilai p-value sebesar 0,002. Hal ini berarti semakin besar pendapatan, maka kontribusi dalam mengambil keputuan akan semakin besar begitu pula sebaliknya.

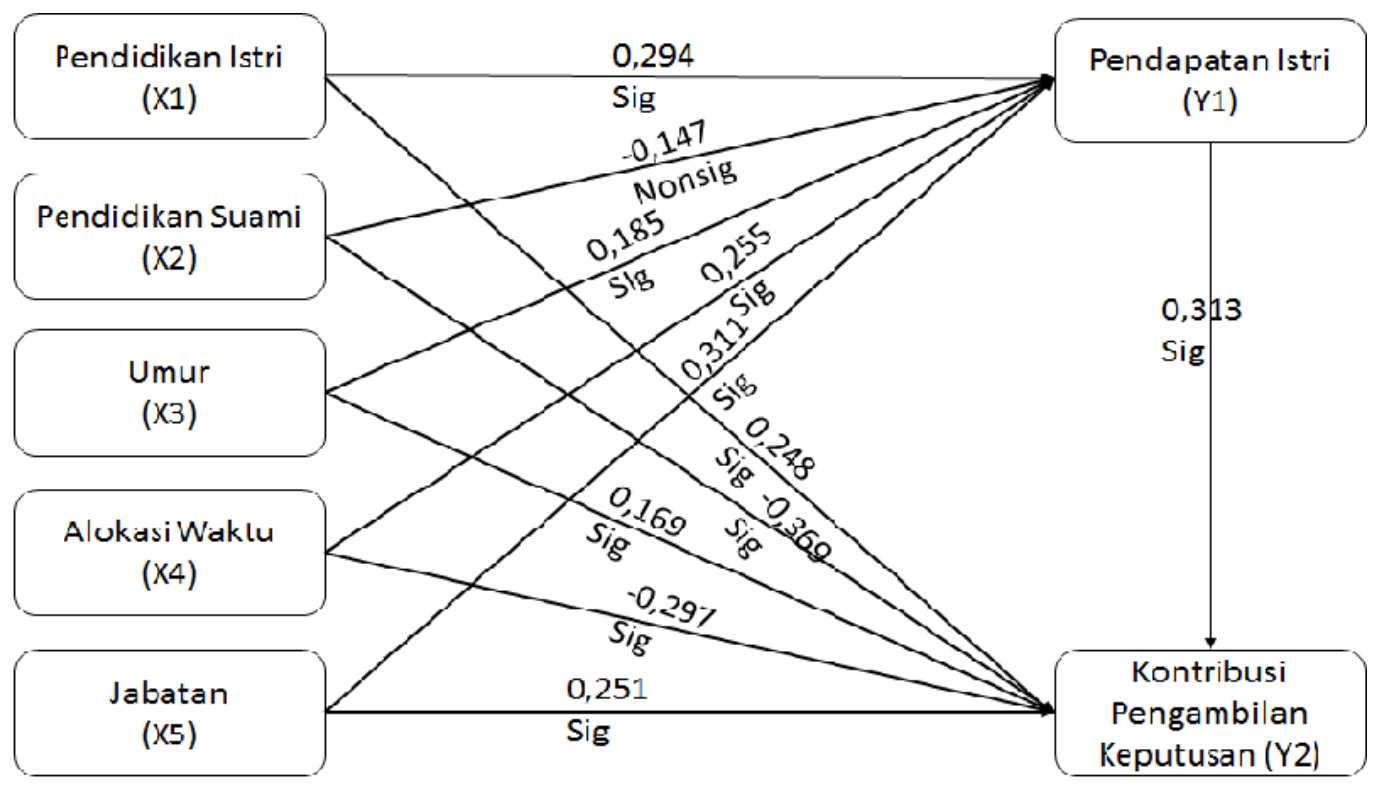

Gambar 2

Diagram Jalur Penelitian

\section{Pengaruh Tidak Langsung}

Hasil pengujian pengaruh tidak langsung antara variabel pendidikan istri, pendidikan suami, umur, alokasi waktu, dan jabatan terhadap kontribusi pengambilan keputusan dengan pendapatan istri sebagai mediasi dapat dilihat pada tabel 5.13 berikut.

\section{Tabel 4}

Hasil Uji Mediasi

\begin{tabular}{llcccc}
\hline Variabel & Variabel & Variabel & $\begin{array}{c}\text { Probabilitas } \\
\text { terhadap }\end{array}$ & $\begin{array}{c}\text { Probabilitas } \\
\text { terhadap }\end{array}$ & Keterangan \\
Eksogen & Mediasi & Endogen & Variabel & Variabel & \\
\hline
\end{tabular}


ISSN : 2337-3067

E-Jurnal Ekonomi dan Bisnis Universitas Udayana 7.4 (2018):1023-1050

Mediasi Endogen

\begin{tabular}{|c|c|c|c|c|c|}
\hline $\begin{array}{l}\text { Pendidikan } \\
\text { Istri }\end{array}$ & $\begin{array}{l}\text { Pendapatan } \\
\text { Istri }\end{array}$ & $\begin{array}{l}\text { Kontribusi } \\
\text { Pengambilan } \\
\text { Pendapatan }\end{array}$ & 0,001 & 0,006 & Signifikan \\
\hline $\begin{array}{l}\text { Pendidikan } \\
\text { Suami }\end{array}$ & $\begin{array}{l}\text { Pendapatan } \\
\text { Istri }\end{array}$ & $\begin{array}{l}\text { Kontribusi } \\
\text { Pengambilan } \\
\text { Pendapatan }\end{array}$ & 0,086 & 0,000 & $\begin{array}{l}\text { Non } \\
\text { Signifikan }\end{array}$ \\
\hline Umur & $\begin{array}{l}\text { Pendapatan } \\
\text { Istri }\end{array}$ & $\begin{array}{l}\text { Kontribusi } \\
\text { Pengambilan } \\
\text { Pendapatan }\end{array}$ & 0,033 & 0,050 & Signifikan \\
\hline $\begin{array}{l}\text { Alokasi } \\
\text { Waktu }\end{array}$ & $\begin{array}{l}\text { Pendapatan } \\
\text { Istri }\end{array}$ & $\begin{array}{l}\text { Kontribusi } \\
\text { Pengambilan } \\
\text { Pendapatan }\end{array}$ & 0,004 & 0,012 & Signifikan \\
\hline Jabatan & $\begin{array}{l}\text { Pendapatan } \\
\text { Istri }\end{array}$ & $\begin{array}{l}\text { Kontribusi } \\
\text { Pengambilan } \\
\text { Pendapatan }\end{array}$ & 0,001 & 0,002 & Signifikan \\
\hline
\end{tabular}

Sumber: Data Penelitian, 2017

Berdasarkan Tabel 4 menunjukkan bahwa secara individu variabel X1 (pendidikan istri) terhadap pendapatan istri memberikan nilai koefisien sebesar 0,101 dengan tingkat signifikansi sebesar 0,001 di bawah alpa 0,05 . Variabel X1 (pendidikan istri) terhadap kontribusi pengambilan keputusan memberikan nilai koefisien sebesar 0,082 dengan tingkat signifikansi sebesar 0,006 di bawah alpa 0,05 . Kedua variabel ini dapat disimpulkan berpengaruh terhadap kontribusi pengambilan keputusan. Hasil ini menunjukkan bahwa secara parsial variabel pendapatan istri memediasi pengaruh variabel pendidikan istri terhadap kontribusi pengambilan keputusan pada rumah tangga perempuan PNS di Kabupaten Tabanan.

Variabel X2 (pendidikan suami) terhadap pendapatan istri memberikan nilai koefisien sebesar -0,047 dengan tingkat signifikansi sebesar 0,086 di atas alpa 0,05. Variabel X2 (pendidikan suami) terhadap kontribusi pengambilan keputusan memberi 
nilai koefisien sebesar -0,113 dengan tingkat signifikansi sebesar 0,000 di bawah alpa 0,05. Hasil ini menunjukkan bahwa secara parsial variabel pendapatan istri tidak memediasi pengaruh variabel pendidikan suami terhadap kontribusi pengambilan keputusan pada rumah tangga perempuan PNS di Kabupaten Tabanan.

Variabel X3 (umur) terhadap terhadap pendapatan istri memberikan nilai koefisien sebesar 0,018 dengan tingkat signifikansi sebesar 0,033 di bawah alpa 0,05. Variabel X3 (umur) terhadap kontribusi pengambilan keputusan memberikan nilai koefisien sebesar 0,015 dengan tingkat signifikansi sebesar 0,050 yang sama dengan alpa 0,05. Kedua variabel ini dapat disimpulkan berpengaruh terhadap kontribusi pengambilan keputusan. Hasil ini menunjukkan bahwa secara parsial variabel pendapatan istri memediasi pengaruh variabel umur terhadap kontribusi pengambilan keputusan pada rumah tangga perempuan PNS di Kabupaten Tabanan.

Variabel X4 (alokasi waktu) terhadap pendapatan istri memberikan nilai koefisien sebesar 0,196 dengan tingkat signifikansi sebesar 0,004 di bawah alpa 0,05. Variabel X4 (alokasi waktu) terhadap kontribusi pengambilan keputusan memberikan nilai koefisien sebesar -0,220 dengan tingkat signifikansi sebesar 0,001 di bawah alpa 0,05. Kedua variabel ini dapat disimpulkan berpengaruh terhadap kontribusi pengambilan keputusan. Hasil ini menunjukkan bahwa secara parsial variabel pendapatan istri memediasi pengaruh variabel alokasi waktu terhadap kontribusi pengambilan keputusan pada rumah tangga perempuan PNS di Kabupaten Tabanan.

Variabel X5 (jabatan) terhadap pendapatan istri memberikan nilai koefisien sebesar 0,464 dengan tingkat signifikansi sebesar 0,001 di bawah alpa 0,05. Variabel 
X5 (jabatan) terhadap kontribusi pengambilan keputusan memberikan nilai koefisien sebesar 0,301 dengan tingkat signifikansi sebesar 0,012 di bawah alpa 0,05. Kedua variabel ini dapat disimpulkan berpengaruh terhadap kontribusi pengambilan keputusan. Hasil ini menunjukkan bahwa secara parsial variabel pendapatan istri memediasi pengaruh variabel jabatan terhadap kontribusi pengambilan keputusan pada rumah tangga perempuan PNS di Kabupaten Tabanan.

\section{Pengaruh Langsung, Pengaruh Tidak Langsung, dan Pengaruh Total}

Tabel 5 menunjukan merupakan koefisien jalur pengaruh langsung sedangkan ringkasan pengaruh langsung sedangkan ringkasan pengaruh langsung, tidak langsung, dan pengaruh total dapat dilihat pada table 5 berikut.

\section{Tabel 5}

Ringkasan Pengaruh Langsung, Pengaruh Tidak Langsung, Dan Pengaruh Total antar Variabel Penelitian

\begin{tabular}{ccccccc}
\hline Konatruk & \multicolumn{6}{c}{ Konstruk Dependen } \\
\cline { 2 - 7 } Independen & \multicolumn{5}{c}{ Y1 } & \multicolumn{3}{c}{ Y2 } \\
\cline { 2 - 7 } & PL & PTL & PT & PL & PTL & PT \\
\hline X1 & 0,294 & - & 0,294 & 0,248 & 0,092 & 0,34 \\
X2 & $-0,147 *$ & - & 0,147 & $-0,369$ & $-0,046$ & $-0,415$ \\
X3 & 0,185 & - & 0,185 & 0,169 & 0,058 & 0,227 \\
X4 & 0,255 & - & 0,255 & $-0,297$ & 0,080 & $-0,217$ \\
X5 & 0,311 & - & 0,311 & 0,251 & 0,097 & 0,348 \\
& & & & 0,313 & & \\
\hline
\end{tabular}

Sumber: Data Penelitian, 2017

Berdasarkan table 5 dijelaskan bahwa secara langsung variabel jabatan memiliki pengaruh paling dominan terhadap pendapatan istri dengan nilai sebesar 0,311, dan secara langsung variabel pendapatan memiliki pengaruh paling dominan terhadap kontribusi pengambilan keputusan dengan nilai sebesar 0,313. Secara tidak 
langsung variabel jabatan melalui pendapatan istri memiliki pengaruh paling dominan terhadap pengambilan keputusan dengan nilai sebesar 0,097 , dan secara total nilai terbesar adalah variabel jabatan sebesar 0,348.

\section{Pembahasan Hasil Penelitian}

Kontribusi perempuan dalam mengambil keputusan merupakan hal yang sangat penting dalam menjaga keseimbangan rumah tangga. Era yang modern dan sudah di terapkan emansipasi wanita, telah menjadikan perempuan di masa sekarang yang sudah memiliki kesetaraan dalam berbagai hal misalnya pendidikan, politik, pengetahuan dan lainnya. Bahkan tak sedikit dari para perempuan tersebut memiliki pendidikan atau jabatan yang lebih dari suaminya. Oleh sebab itu, perempuan juga sangat berperan dalam mengambil keputusan dalam keluarganya. Kontribusi dalam mengambil keputusan dalam rumah tangga perempuan yang telah menikah di Kabupaten Tabanan masih belum setara antara suami dan istri, hal ini terlihat bahwa pengambilan keputusan dalam rumah tangga para perempuan tersebut masih dalam bidang pendidikan anak saja, sedangkan dalam bidang yang lain masih belum mencapai kesetaraan. Hal in membuktikan bahwa masih ada anggapan perbedaan gender dan seorang suami juga yang harus menentukan keputusan dalam keluarga.

Banyak hal yang bisa dirundingkan dalam keluarga, seperti misalnya masalah pendidikan anak, urusan rumah tangga, keuangan, mebanjar dan lain sebagainya. Peran perempuan dalam mengambil keputusan juga sangat penting untuk terjalinnya keharmonisan keluarga dan saling mengisi antara suami dan istri. Oleh sebab itu, pentingnya keikutsertaan seorang istri dalam menentukan keputusan di rumah tangga 
baik itu untuk kelurga, maupun yang lainnya. Perlunya rasa saling menghargai antara suami dan istri dalam rumah tangga agar tercapainya pengambilan keputusan yang lebih maksimal dalam rumah tangga. Namun, tidak jarang juga perempuan yang sudah berkontribusi dalam pengambilan keputusan dan tidak jarang juga seorang suami mempercayakan masalah keuangan dan rumah tangga terhadap istrinya.

Pendidikan istri berpengaruh positif dan berpengaruh langsung terhadap pendapatan istri. Pendapatan dipengaruhi tingkat pendidikan sebagai salah satu faktor yang mempengaruhi (Cahyono, 1998). Pendidikan suami berpengaruh negatif dan tidak signifikan terhadap pendapatan istri, hal ini berarti pendidikan suami tidak terkait dengan tinggi rendahnya pendapatan istri. Umur berpengaruh positif dan memiliki pengaruh langsung terhadap pendapatan istri. Pendapatan juga dipengaruhi oleh umur seseorang. (Cahyono, 1998). Umur pada masa produktif berkisar antara 15-64 tahun yang merupakan umur ideal bagi para pekerja. Alokasi waktu berpengaruh positif dan memiliki pengaruh langsung terhadap pendapatan istri. Semakin tua seseorang maka tanggung jawab terhadap keluarga juga besar. Semakin tinggi alokasi perempuan dalam bekerja maka semakin tinggi pula pendapatan yang diterima olehnya. Jabatan berpengaruh positif dan memiliki pengaruh langsung terhadap pendapatan istri. Jabatan yang tinggi akan mempenagruhi pendapatan dalam dunia kerja. Hal ini di dukung oleh penelitian Iklima (2014) yang mengatakan bahwa jabatan tinggi di tempat kerja menyebabkan pendapatan yang diterima juga akan tinggi. 
Pendidikan istri berpengaruh positif dan berpengaruh langsung terhadap pendapatan istri. Pendapatan merupakan salah satu faktor yang mempengaruhi tingkat pendidikan (Cahyono, 1998). Pendidikan merupakan suatu wahana untuk mencapai suatu tujuan yang diinginkan/dipersyaratkan untuk menjebatani kesenjangan antara tingkat yang telah dicapai dengan tingkat pendidikan. Pendidikan istri merupakan hal yang sangat penting dalam mencapai kesejahteraan, baik pendidikan formal maupun non formal.

Pendidikan suami tidak berpengaruh positif dan signifikan terhadap pendapatan istri. Hasil tersebut berarti pendidikan suami tidak memiliki berpengaruh terhadap pendapatan. Tinggi rendahnya pendidikan suami tidak mempengaruhi tingkat pendapatan istri. Dimana pendidikan istri lebih diukur dari pendidikan suami.

Umur berpengaruh positif dan signifikan terhadap pendapatan istri. Hal ini berarti bahwa umur berpengaruh positif dan memiliki pengaruh langsung terhadap pendapatan istri. Pendapatan dipengaruhi oleh salah satu faktor yaitu umur (Cahyono, 1998). Umur produktif yang ideal bagi para pencari kerja berkisar antara 15-64 tahun. Bergantung pada jenis pekerjaan yang dilakukan, pada usia produktif semakin bertambahnya umur seseorang maka pendapatannya pun akan berubah, begitu juga sebaliknya.

Alokasi waktu berpengaruh positif dan signifikan terhadap pendapatan istri. Hal ini berarti bahwa alokasi waktu berpengaruh positif dan memiliki pengaruh langsung terhadap pendapatan istri. Semakin bertambah umur seseorang maka tanggung jawab terhadap keluarga juga besar. Semakin tinggi alokasi perempuan 
dalam bekerja maka semakin tinggi pula pendapatan yang diterima olehnya. Hal ini diperkuat dengan hasil penelitian Widiandarini (2001) dalam Handayani (2009), curahan jam kerja laki-laki lebih kecil dibanding perempuan. Ini menunjukan bahwa perempuan memiliki peranan yang cukup besar dalam rumah tangga, yaitu dalam membantu memenuhi kebutuhan rumah tangga.

Jabatan memiliki pengaruh positif dan signifikan terhadap pendapatan istri. Hal ini berarti bahwa jabatan berpengaruh positif dan memiliki pengaruh langsung terhadap pendapatan istri. Jabatan yang tinggi akan mempenagruhi pendapatan dalam dunia kerja. Hal ini di dukung oleh penelitian Iklima (2014) yang mengatakan bahwa jabatan tinggi di tempat kerja menyebabkan pendapatan yang diterima juga akan tinggi. Tingginya kebutuhan yang menyebabkan seorang istri harus ikut terjun dalam dunia kerja bahkan hingga memiliki jabatan yang tinggi sesuai dengan jenjang pendidikan atau bahkan pengalaman.

Pendapatan istri memediasi secara parsial pengaruh pendidikan istri terhadap kontribusi pengambilan keputusan perempuan PNS yang telah menikah di Kabupaten Tabanan, sehingga dapat diartikan bahwa pendidikan istri berpengaruh positif dan signifikan terhadap pendapatan istri. Semakin tinggi pendidikan istri maka akan mempengaruhi dalam kontribusi seorang istri dalam mengambil keputusan dalam rumah tangga. Hal ini di dukung oleh jurnal Bustami (2013) yang menyatakan bahwa semakin tinggi pendidikan akan mempengaruhi peran perempuan dalam keluarga terutama dalam pengambilan keputusan dalam rumah tangga. 
Pendapatan istri tidak memediasi pengaruh pendidikan suami terhadap kontribusi pengambilan keputusan oleh perempuan PNS yang telah menikah di Kabupaten Tabanan. Hal ini disampaikan Bustami (2013) bahwa pendidikan suami berpengaruh signifikan terhadap kontribusi seorang istri dalam mengambil keputusan dalam rumah tangga.

Pendapatan istri memediasi secara parsial pengaruh umur terhadap kontribusi pengambilan keputusan perempuan PNS yang telah menikah di Kabupaten Tabanan, sehingga dapat diartikan bahwa umur berpengaruh positif dan signifikan terhadap pendapatan istri dari perempuan PNS yang telah menikah di kabupaten Tabanan. Menurut Alberth (2012) menyatakan bahwa faktor umur berpengaruh positif dan signifikan terhadap kontribusi pengambilan keputusan dalam rumah tangga.

Pendapatan istri memediasi secara parsial pengaruh alokasi waktu terhadap kontribusi pengambilan keputusan perempuan PNS yang telah menikah di Kabupaten Tabanan, sehingga dapat diartikan bahwa alokasi waktu berpengaruh negatif dan signifikan terhadap pendapatan istri dari perempuan PNS yang telah menikah di kabupaten Tabanan. Menurut Alberth (2012) alokasi waktu untuk bekerja memiliki pengaruh negatif dan signifikan terhadap kontribusi pengambilan keputusan dalam rumah tangga.

Pendapatan istri memediasi secara parsial pengaruh jabatan terhadap kontribusi pengambilan keputusan perempuan PNS yang telah menikah di Kabupaten Tabanan. Jabatan yang tinggi akan mempengaruhi seorang istri dalam kontribusinya mengambil keputusan. Hal ini didukung pernyataan Rochaeni dan Lokollo (2005) 
yang mengatakan bahwa jabatan berpengaruh positif dan signifikan terhadap pengambilan keputusan dalam rumah tangga.

\section{SIMPULAN DAN SARAN}

Pendidikan istri, umur, alokasi waktu, dan jabatan berpengaruh positif dan signifikan terhadap pendapatan istri PNS perempuan yang telah menikah di Kabupaten Tabanan. Adapun variabel pendidikan suami berpengaruh negatif dan tidak signifikan terhadap pendapatan istri PNS perempuan yang telah menikah di Kabupaten Tabanan. Pendapatan istri memediasi pengaruh pendidikan istri, umur, alokasi waktu dan jabatan terhadap kontribusi pengambilan keputusan PNS perempuan yang telah menikah di Kabupaten Tabanan. Adapun variabel pendapatan istri tidak memediasi pengaruh pendidikan suami terhadap kontribusi pengambilan keputusan PNS perempuan yang telah menikah di Kabupaten Tabanan.

Sebaiknya kepada para istri dan suami mampu memahami dengan benar peran antara lelaki dan perempuan, hak dan kewajiban suami dan istri dalam keluarga sesuai agar memiliki kesetaraan dalam mengambil keputusan dalam rumah tangga. Pendidikan suami yang semakin tinggi seharusnya membuat suami bisa lebih menghargai kehadiran istri dan lebih mengerti bahwa harus bisa mengurus keluarga secara beriringan, saling membantu dan melengkapi. Pendidikan yang tinggi, umur, alokasi waktu, jabatan dan pendapatan istri yang tinggi tidak membuat istri berkontribusi banyak dalam rumah tangga, seharusnya istri lebih dilibatkan dan lebih bisa ikut aktif dalam mengatur keluarganya dalam hal lain selain mengurus anak. 


\section{DAFTAR PUSTAKA}

Alatas (Syed), Husein. 1990. Corruption: Its Nature, Causes, and Functions. Political Science.

Alberth, Risyart. 2012. Peran Gender Dalam Kehidupan Rumah Tangga Di Desa Liang Kabupaten Maluku Tengah. Jurnal Agribisnis Kepulauan Volume 1 No. 1.

Ariastuti, Ni Gusti dan Made Antara. 2008. Faktor-faktor Yang Menentukan Loyalitas Pelanggan Terhadap Merek Teh Botol Sosro di Kota Denpasar. Jurnal Agribisnis, Jurusan Sosial Ekonomi Pertanian Fakultas Pertanian Universitas Udayana.

Ariesta, Putri Septyaning Rahayu. 2014. Peran Sosial Perempuan dalam Keluarga dan Masyarakat. Universitas Airlangga. Surabaya.

Becker, Gary S. 1965. A Theory of the Allocation of Time. The Economic Journal, Vol. 75, No. 299, 493-517.

Bustami. 2013. Peran Ibu Rumah Tangga Dalam Keluarga (Kasus Ibu-Ibu Yang Bekerja Sebagai Guru Sekolah Dasar) Di Kecamatan Tanjungpinang Barat. Universitas Maritim Raja Ali Haji. Tanjung Pinang.

Bogdan, R and Taylor, S, J. 1975. "Introducing to Qualitative Research Methode". New York: John Willey and Sons.

Botkin, D. R., Weeks, M. O., \& Morris, J. E. (2000). Changing marriage role expectations:1961-1996. Sex Role, 42, 933-942.

Cahyono, S. Andy. 1998. Karakteristik Sosial Ekonomi yang Mempengaruhi Pendapatan Rumah Tangga Penyadap Getah Pinus di Desa Somagede, Kebumen, Jawa Tengah. Jurnal UGM.

Claffey, S. T., \& Mickelson, K. D. (2009). Division of Household Labor and Distress: The Role of Perceived Fairness for Employed Mothers. Sex Role, 819-831.

Engels, F (1972) The Origin of The Family, Private Property and The State, Lawrence dan Wishart, London.

Febriani. 2012. Peran Wanita Dalam Pengembangan Usaha Kecil Dan Menengah Di Kota Padang. Jurnal Manajemen dan Kewirausahaan, Volume 3, Nomor 3, 
September 2012.

Fukuyama, F. 2000. The Great Disruption: Human Nature and the Reconstitution of Social Order, Profile Books Ltd., London.

Handayani, M.TH. dan Artini. 2009. Kontribusi Pendapatan Ibu Rumah Tangga Pembuat Makanan Olahan Terhadap Pendapatan Keluarga. Piramida, Vol.V No.1,:9-15.

Haryanto, Sugeng. 2008. Peran Aktif Wanita Dalam Peningkatan Pendapatan Rumah Tangga Miskin: Studi Kasus Pada Wanita Pemecah Batu Di Pucanganak Kecamatan Tugu Trenggalek. Jurnal Ekonomi Pembangunan Vol. 9, No. 2, Desember 2008, hal. 216 - 227.

Iklima. 2014. Peran Wanita Karir Dalam Melaksanakan Fungsi Keluarga (Studi Kasus Pns Wanita Yang Telah Berkeluarga Di Balai Kota Bagian Humas Dan Protokol Samarinda). eJournal Sosiaatri Integratif, 2014, 2 (3 ): 77-89.

Konrad, A., \& Harris, C. (2002). Desirability of the Bem sex-role inventory items for women and men: A comparison between African Americans and European Americans sex roles. Journal of Sex Research, 2, 45-52.

Laporan Penelitian Bank Dunia, 2002. Pembangunan Berperspektif Gender, Engendering Development Melalui Perspektif Gender Dalam Hak, Sumberdaya, dan Asprirasi. Laporan Penelitian Bank Dunia, Dian Rakyat. Jakarta.

Lee, Y.-S., \& Waite, L. J. (2005). Husband and Wife Time Spent on Housework: A Comparison of Measures. Journal Marriage and Family, 67, 328-338.

Lewin-Epstein, N., Stier, H., \& Braun, M. (2006). The Division of Household Labor in Germany. Journal of Marriage and Family, 1147-1164.

MacCormack C.P. dan Stratern, M. 1980, "Nature, Culture and Gender: A Critique",dalam MacCormack C.P. dan Stratern, M. Nature, Culture and Gender, Cambridge University Press, Cambridge.

Mudzhar, H. M. Atho., Sajida A. Alvi., dan Saparinah Sadli. (Eds.). 2001. Wanita di dalam Masyarakat Indonesia: Akses, Pemberdayaan dan Kesempatan. Yogyakarta: Sunan Kalijaga Press.

Olson, D., \& Defrain, J. (2003). Marriages and families: Intimacy, diversity, and strengths. New York: McGraw-Hill Higher Education. 
Puspitawati, H. (2010). Analisis Structural Equation Modelling Tentang Relasi Gender, Tingkat Stres, Dan Kualitas Perkawinan Pada Keluarga Penerima Program Keluarga Harapan (PKH). Jurnal Studi Gender \& Anak, 5(2), 328345.

Rochaeni, Siti dan Erna M. Lokollo. 2005. Faktor- Faktor yang Mempengaruhi Keputusan Ekonomi Rumah Tangga Petani di Kelurahan Setugede Kota Bogor. Jurnal Agro Ekonomi Volume 23 No. 2.

Spigel, Henry. W. 1983. The Growth of Economic Thonght Revised andExpandend Edition. Durham North Carolina: Duke University.

Stevenson, F.J. 1994. Humus Chemistry: Journal Genesis, Composition, Reactions, 2nd Edition.

Sunaryo dan Zuriah, 2004. Laporan Penelitian: Pola Pengambilan Keputusan dalam Keluarga Wanita Karier di kota Malang. Pusat Studi Wanita dan Kemasyarakatan Lembaga Penelitian. Universitas Muhamadiyah Malang.

Suyana Utama, Made. 2015. Modul Metode Kuantitatif. Denpasar: Program MIE Fakultas Ekonomi dan Bisnis Universitas Udayana

Vayda, Andrew R 1998. Enviroment and Cultural Behavior. New York, The Natural History Press.

Walgito, B. 2000. Bimbingan dan Konseling Perkawinan. Yogyakarta: Andi Offset.

Wiludjeng, dkk. 2005. Dampak Pembakuan Peran Gender Terhadap Perempuan Kelas Bawah di Jakarta. Jakarta: LBH-APIK. 